\title{
Field studies on retention of the planktonic copepod Eurytemora affinis in a mixed estuary
}

\author{
A. R. Hough, E. Naylor \\ School of Ocean Sciences, University of Wales, Bangor, Menai Bridge, Gwynedd, United Kingdom
}

\begin{abstract}
The retention mechanism of a population of the estuarine copepod Eurytemora affinis (Poppe) was determined within a strongly tidal, mixed estuary. Sampling in the water column at sites along the estuary was carried out to assess any tidal. diel and semilunar patterns of change. The species showed distinct tidal differences in abundance with horizontal position, being maximally abundant on the flood tide at the most seaward site and on the ebb tide at the landward site, suggesting differential tidal swimming, leading to accumulation at an intermediate point. Monitoring over a springs-neapssprings cycle suggested that the position of this point changed over the semi-lunar cycle, with greatest numbers on flood tides over springs and on ebb tides over neaps. This was confirmed by repeated sampling along the length of the estuary; a specific region was identified where very high numbers of E. affinis occurred. This horizontal position changed between springs and neaps, apparently maintaining the bulk of the population within a specific salinity zone. Sampling throughout the water column showed these horizontal movements to be facilitated by tidal vertical migrations.
\end{abstract}

\section{INTRODUCTION}

The copepod Eurytemora affinis (Poppe) is a common and widespread, truly estuarine crustacean which is an ideal subject for the study of position maintenance behaviour in small planktonic estuarine organisms. The species has been found to consistently maintain populations within an environment of net seaward flow (Cronin et al. 1962, Jeffries 1962, Heinle \& Flemer 1975, Von Vaupel-Klein \& Weber 1975, Knatz 1978, Collins \& Williams 1981, Soltanpour-Gorgari \& Weltershaus $1985,1987)$. It is found in varying abundances along estuaries, with high numbers in the low salinity zone (Roddie et al. 1984, Soltanpour-Gargari \& Wellershaus 1987, Castel \& Veiga 1990) and low numbers at salinities of $30 \%$ and above (for example Collins \& Williams 1981). A mechanism must therefore exist to prevent, or compensate for, catastrophic transport of animals seawards.

Several theories have been formulated to explain the maintenance of plankton populations in estuaries. Passive transport in water moving upstream has been proposed for some estuarine plankton species (Rogers 1940, Bosch \& Taylor 1973, De Wolf 1973, 1986, Seliger et al. 1982), and more specifically for Eurytemora affinis (Castel \& Viega 1990). Also Ketchum (1954) suggested the replacement of animals exported sea- wards occurred as a result of a high reproductive potential in estuarine species. Barlow (1955), however, calculated that an Acartia species could not be maintained in an estuary by reproduction alone and suggested instead that recruitment occurred from a deeper-water population removed from the seawardflowing upper layers. Moreover, there is certainly no published evidence that estuarine copepods have a greater reproductive potential than related marine species. Soltanpour-Gargari \& Wellershaus (1987), in explaining a landward distribution of $E$. affinis, proposed a similar mechanism to that suggested by Barlow (1955), with the added proposal that larval release occurred predominantly on flood tides, leading to an upstream displacement of the population.

Retention strategies among planktonic species based on selective use of tidal transport have been suggested for Acartia longipatella (Wooldridge \& Erasmus 1980), larvae of the estuarine crab Rhithropanopeus harisii (Cronin 1982) and oyster larvae (Wood \& Hargis 1971). Other behavioural mechanisms proposed specifically for Eurytemora affinis include an active anadromous migration against the prevailing water movement (Heckman 1986) and sinking of copepods, either actively or passively, out of the water column on encountering high salinities (De Pauw 1973, Von Vaupel-Klein \& Weber 1975). 
This paper considers the horizontal position, tidal abundances and vertical distribution of Eurytemora affinis in a strongly tidal, mixed estuary on the west coast of Britain. Numbers of individuals and their position in the water column were determined at various states of the tide, together with variations in abundance associated with the season, semi-lunar cycle and position along the estuary. An attempt is also made to develop a testable hypothesis concerning the relative importance of upward-swimming behaviour and hydrographic processes in controlling the distribution and retention of $E$ affinis in such an estuary, representing possibly the harshest type of environment for the retention of planktonic species so far studied.

\section{MATERIALS AND METHODS}

Study area. Sampling was carried out in the Conwy Estuary, the largest estuary on the North Wales coast where tidal ranges in excess of $10 \mathrm{~m}$ amplitude are common. Physical conditions have been extensively studied in the estuary (Knight \& West 1975, Hunter \& Lailey 1980, Pelegri 1988) and the following physical description is based mainly on these accounts. Mean tidal amplitudes are $3.8 \mathrm{~m}$ on neaps and $6.0 \mathrm{~m}$ on springs, values significantly lower than those on the open coast due to a narrowing of the channel near to the mouth. Nevertheless, current speeds are considerable, with maximum velocities of $2.28 \mathrm{~m} \mathrm{~s}^{-1}$ in the outer estuary, $1.48 \mathrm{~m} \mathrm{~s}^{-1}$ in mid-estuary and $60 \mathrm{~cm} \mathrm{~s}^{-1}$ in the upper estuary. These result in uni-directional flow on both flood and ebb tides, with sufficient mixing on both to prevent stratification.

Despite the differences in velocity between spring and neap tides, with maximum current speeds in midestuary ranging from $1.48 \mathrm{~m} \mathrm{~s}^{-1}$ on springs to $0.94 \mathrm{~m} \mathrm{~s}^{-1}$ on neaps, there is mixing on both. Some stratification takes place in the lower estuary between 2.5 and $3 \mathrm{~h}$ after low water, but this is soon destroyed during the flood tide. Consequently only low levels $(<2 \%$ of vertical and lateral stratification are found. River input into the estuary averages $17.4 \mathrm{~m}^{3} \mathrm{~s}^{-1}$ from the River Conwy and a further $3 \mathrm{~m}^{3} \mathrm{~s}^{-1}$ from tributaries. As the amount of tidal penetration decreases upstream, there is consequently a longer period of river flow at low water At low tide the estuary drains, almost to the mouth, where stratification begins.

Sampling. The relative number of Eurytemora affinis present in the water column over each tide was determined using portable 'drift' nets $(1 \mathrm{~m} \times 1 \mathrm{~m}$ aperture size, $0.2 \mathrm{~mm}$ mesh), held in a square steel frame. Two nets were arranged, one facing downstream (seaward) the other upstream. Preliminary trials showed little or no loss of copepods from the downstream facing net

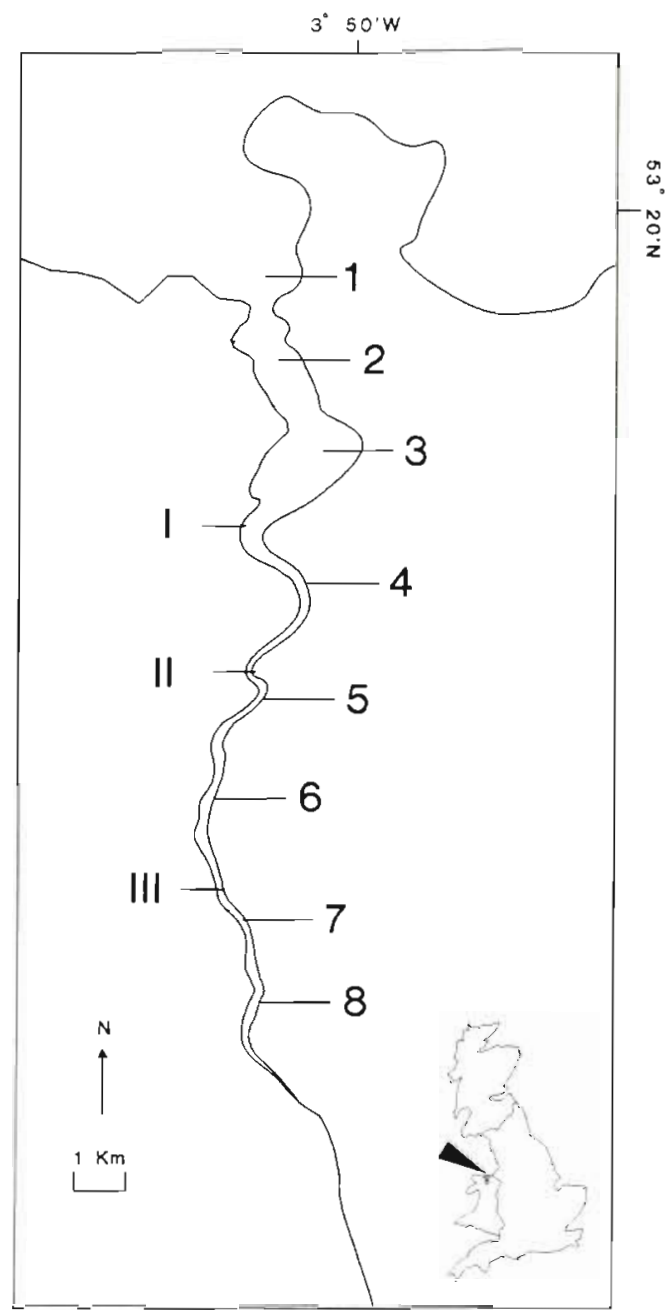

Fig. 1. The Conwy Estuary with drift-net sampling sites (I to III), and boat-sampling stations (1 to 8 ) marked

after being left in place during the ebb tide. Consequently the nets were placed at the water's edge at low water and emptied on the following low tide. These nets were used to investigate both the tidal abundances of Eurytemora affinis at 3 sites along the estuary (A), and semi-lunar differences in abundance at a fixed site (B).

(A) Sampling along the estuary took place at Sites I, II and III (Fig, 1) on a total of 9 separate occasions between May 1988 and January 1989, at times of spring tides of increasing amplitude.

(B) Abundance in the water column over the semilunar cycle was determined over each tide at Site I from 25 February, on spring tides of decreasing amplitude, to 9 March 1989 , when spring tides were again increasing in amplitude. The 'drift' nets were placed slightly above mean low water level, emptied on each low tide and then reset before the following flood tide. This provided samples over 24 consecutive tidal cycles.

To measure the distribution of copepods throughout the water column, 2 further groups of 3 nets were used, 
each of $20 \times 20 \mathrm{~cm}$ aperture and $0.2 \mathrm{~mm}$ mesh. These were lowered into the water column at Site III where the estuary narrows into a U-shaped section and water is always present at the edge, one group at the river edge and the other in mid-channel. The top net of each set was free-running on the anchor rope and attached to a buoy to ensure constant sampling in the upper water layers irrespective of tidal rise and fall, while the other 2 were fixed $0.2 \mathrm{~m}$ and $1.2 \mathrm{~m}$ from the bottom respectively. These nets were lowered for $15 \mathrm{~min}$ every hour from the onset of the daytime flood tide to the end of the following night-time ebb. Sampling was on spring tides when the daytime high tide occurs around midday in North Wales. Tidal amplitudes at Site III are ca $3 \mathrm{~m}$ on spring tides, with a flood tide duration of about $2 \mathrm{~h}$, an ebb tide duration of about $4 \mathrm{~h}$ and a period of low water lasting for around $6 \mathrm{~h}$; samples collected during these times are therefore presented separately.

Copepods were counted in the laboratory by taking the mean of three $1 \mathrm{ml}$ subsamples from a well-mixed dilution of the original sample. Owing to the different sampling times and net apertures, samples taken from the nets used in (A) and (B) were obtained from a dilution to $1 \mathrm{l}$. For the smaller nets a dilution to $100 \mathrm{ml}$ was subsampled in the same way.

Eurytemora affinis distributions along the length of the estuary were investigated by sampling in midchannel from a small boat over a single diurnal high tide period on a seasonal and springs and neaps basis. Surface samples were taken from each of Stns 1 to 8 (Fig. 1), using a handnet of $22 \times 25 \mathrm{~cm}$ aperture and $0.2 \mathrm{~mm}$ mesh, towed at a constant speed relative to the current for $10 \mathrm{~min}$ in mid-channel. Temperature and salinity were also recorded. Sampling was carried out over high tide on the spring tide of greatest amplitude and the neap tide of smallest amplitude over separate semi-lunar cycles in November 1989, March 1990 and June 1990. Abundances are expressed as the estimated total number of copepods calculated from three $1 \mathrm{ml}$ subsamples. Individuals were not measured, and only ovigerous females, identified by the presence of full egg-sacs, were distinguished from the remainder of the population and counted separately.

When comparing the distribution of copepods along the estuary, the 'Centre of Population' (CoP) is used:

$$
\mathrm{CoP}=\frac{\sum\left(N_{i} S_{i}\right)}{N}
$$

where $N_{i}=$ number of individuals at Site $i_{i} S_{i}=$ number of Site $i ; N=\Sigma N_{3}$. This gives a hypothetical site number where the maximum number of individuals would be expected. Numbers obtained during the springsneaps-springs sampling period were standardised for the estimated amount of water filtered. The number of copepods caught per tidal cycle was divided by the estimated maximum velocity at this site for the predicted tidal range, multiplied by the sampling time for flood and ebb tides to give the numbers per estimated $\mathrm{m}^{3}$ Analysis of the distribution of copepods throughout the water column was carried out by regarding each position as a discrete depth and applying the model of McCleave et al. (1987). This procedure, however, is complicated by a lack of data on tidal velocities during sampling, so it was necessary to use the logarithmic velocity profile (Bowden 1983) to give estimated velocities for each net, thus compensating for boundary effects.

\section{RESULTS}

Over the 8 mo of sampling throughout 1988-1989, there was a consistently greater abundance of Eury temora affinis at the times of flood tide at Site I, and at the times of ebb tide at Site III (Fig. 2). Although fewer data are available for Site II, the 2 sets of values obtained show overall abundance to be greatest on the flood tide. Salinities at high tide were consistently greater than $23 \%$ at Site I and less than $11 \%$ at Site III. The abundance on each tidal cycle over the semi-lunar sampling period at Site I (Fig. 3) shows maximum numbers on the flood tide during spring tides, whereas over the neap tides there was a change in net abundance to the ebb tide. There were no consistent differences in abundance between day and night-time samples, implying no diel vertical migration.

The distribution of Eurytemora affinis vertically and laterally throughout the channel was investigated at Site III in May 1989 on a spring tide of increasing amplitude. Large numbers were obtained during both

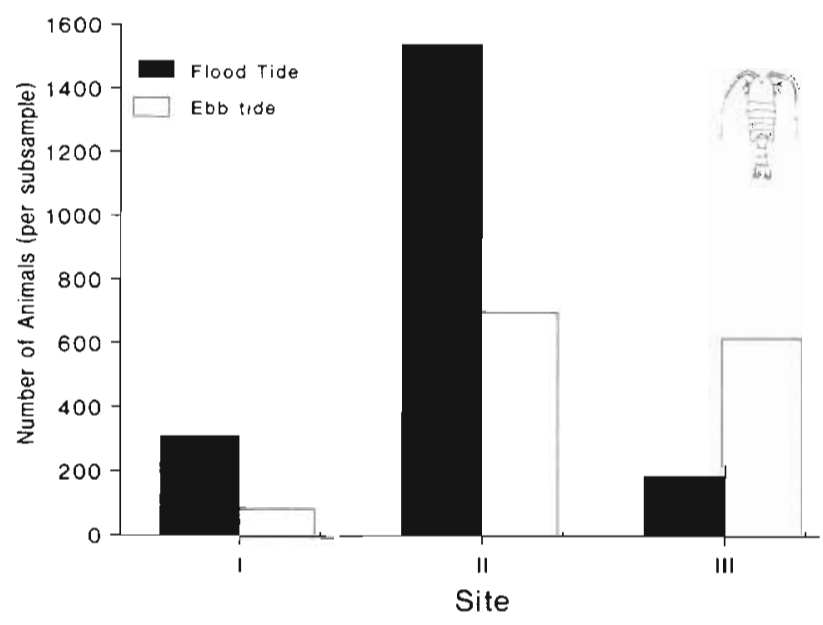

Fig. 2. Eurytemora affinis. Flood and ebb tide abundances (number per $1 \mathrm{ml}$ subsample) at Sites I, II and III, 1988-1989. Number of days of sampling at each site: I $=4$, II $=2$, III $=3$ 
the diurnal and nocturnal tidal cycles (Fig. 4). Interestingly, ovigerous females dominated the population, comprising $82 \%$ of the specimens captured. During both day and night-time samples, greatest numbers of individuals, and the highest vertical displacements, were found on flood tides (Fig. 4), corresponding with the upstream migration expected during spring tides. During both tidal cycles low numbers were found during the periods of normal river flow at low water, when the greatest concentrations were usually found in bottom samples. During the diumal flood tide maximum numbers were found in mid-depth both in the middle and at the edge of the channel, while numbers in top samples were greater than at the bottom. On the daytime ebb tide the distribution was shifted downwards in the water column, more copepods being found in bottom samples than at the top and far fewer being found in the mid-depth samples. Data for the nocturnal tidal cycle also showed a greater concentration of individuals higher in the water column on the flood tide than on the ebb. However, apart from an increased abundance in top samples during the flood tide, the difference between the tides is less clear-cut than during the day. Testing the observed vertical distributions on each tide against those expected assuming a

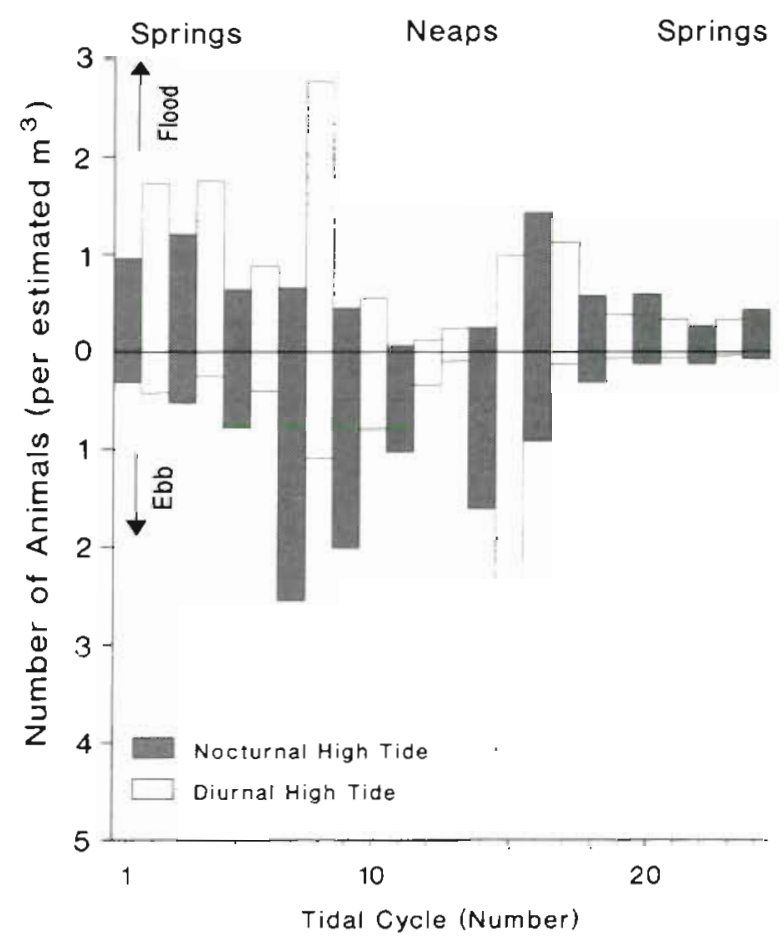

Fig. 3. Eurytemora affinis. Tidal abundances (flood and ebb tides) over a semi-lunar cycle at Site I, Feb-Mar 1989. Each bar represents a single tidal cycle. Numbers are corrected for the estimated amount of water filtered (see text for procedure). Shaded bars: time of high tide occurs at night; open bars: time of high-tide occurs during the day homogeneous distribution (McCleave et al. 1987) shows highly significant differences $(p<0.005)$. The same model also shows these vertical distributions throughout the water column to be significantly different between flood and ebb tides and between ebb tides and at low water, $p<0.005$ for both day and night samples. There was no evidence on either the nocturnal or diurnal tidal cycles of any appreciable difference in the numbers of $E$. affinis found between the edge and middle of the channel.

The results of the investigation into the horizontal positioning of Eurytemora affinis along the estuary on spring and neap tides in November 1989 are illustrated in Fig. 5. The calculated centres of population for the species, and for ovigerous females, together with the estimated temperature and salinity values for these locations calculated from adjacent values, are presented in Table 1 for samples collected in November 1989. March 1990 and June 1990. On each sampling date there were very clearly defined population maxima over 1 or 2 sites and a clear difference between the position of maximum numbers of ovigerous females and that of the rest of the population, as shown in Fig. 5 . The relative position of the ovigerous female maximum, however, varied between sampling dates (Table 1). Over each semi-lunar period there was also a distinct movement of the population downstream from springs to neap tides.

As well as springs-neaps differences in distribution there were also differences in the position of the population between sampling dates. The whole population tended to occur higher up the estuary on both springs and neaps in March 1990 compared with the distribution in November 1989 and June 1990. This cannot be explained on the basis of increased tidal ranges transporting the population upstream in March, as although the predicted spring tidal range increased from $7.5 \mathrm{~m}$ in November to $8.6 \mathrm{~m}$ in March, the neap range decreased from 4.2 to $3.1 \mathrm{~m}$. Both spring and neap distributions, however, showed an upstream displacement. Also, in June there was a lower spring tidal range than in November.

\section{DISCUSSION}

Behavioural mechanisms promoting retention have been demonstrated in several planktonic estuarine species, from zoeae of the crab Rhithropanopeus harrisii (Cronin 1982) and the copepod Acartia longipatella (Wooldridge \& Erasmus 1980) to barnacle nauplii (Bousfield 1955) and oyster larvae (Wood \& Hargis 1971). Yet, despite a number of observations on the zonation of Eurytemora affinis and the relationship of this to salinity (Cronin et al. 1962, Jeffries 1962, Heinle 
\& Flemer 1975, Roddie et al. 1984, Soltanpour-Gargari \& Wellershaus 1987, Castel \& Veiga 1990), there has been no viable explanation of its retention strategy, especially in estuaries of the type of hydrodynamic regime found in the Conwy. The only behavioural explanations - of an active anadromous migration (Heckman 1986) and avoidance of currents in its pre-

\section{EDGE}
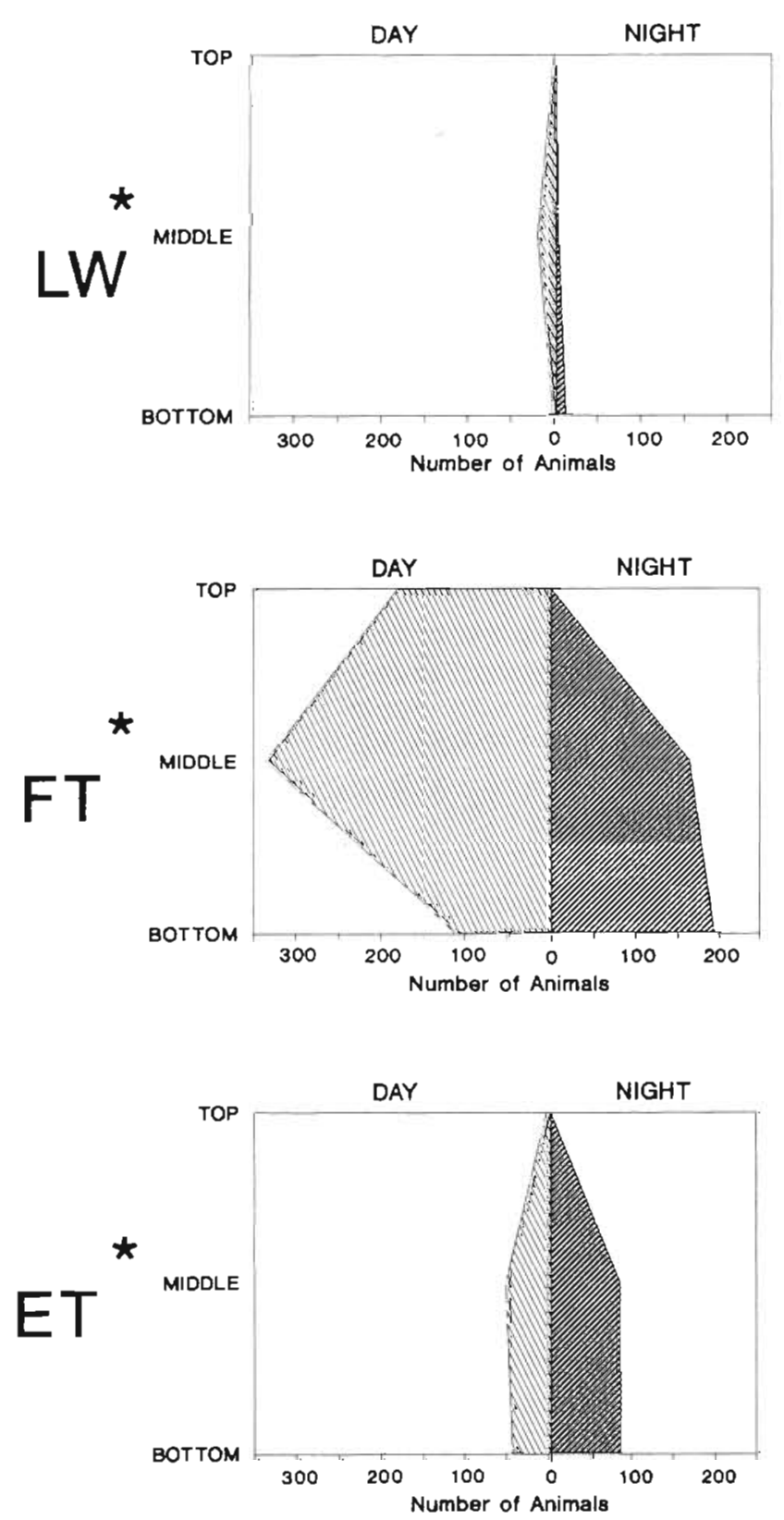
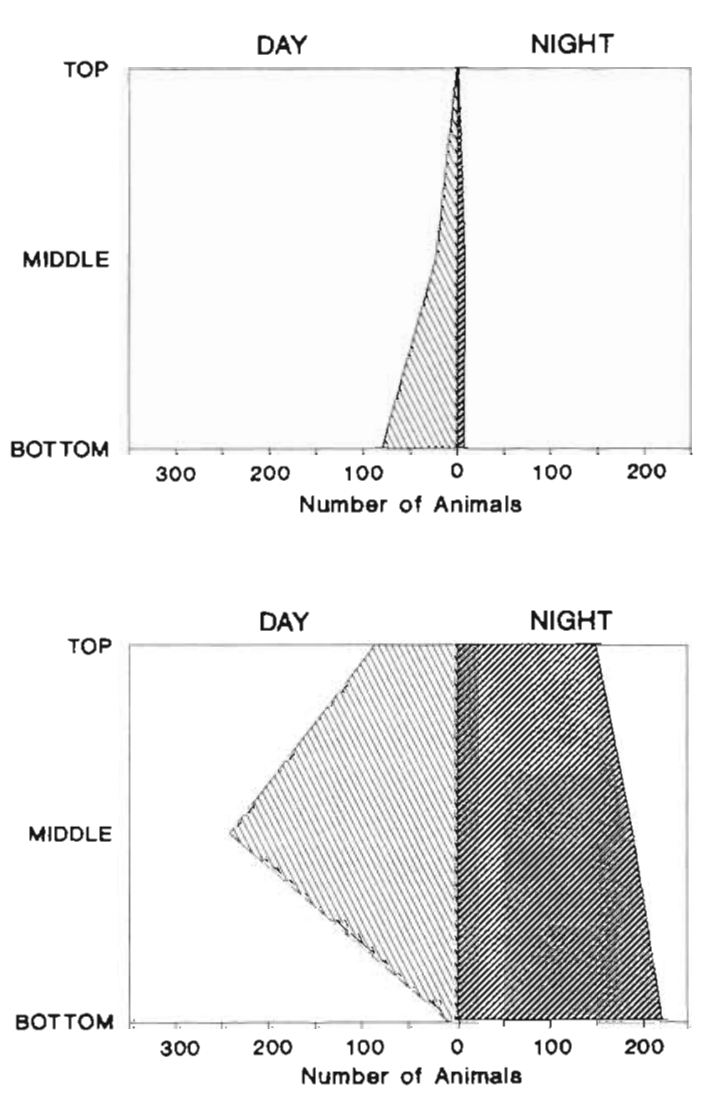

ferred salinity zone (De Pauw 1973, Von Vaupel-Klein \& Weber 1975) - seem to invoke a horizontal swimming capability far greater than that suggested by Castel \& Veiga (1990). The alternative of passive transport, as proposed by Castel \& Viega (1990) would not maintain a planktonic population within this type of environment. The present study implies a strategy based on

MIDDLE

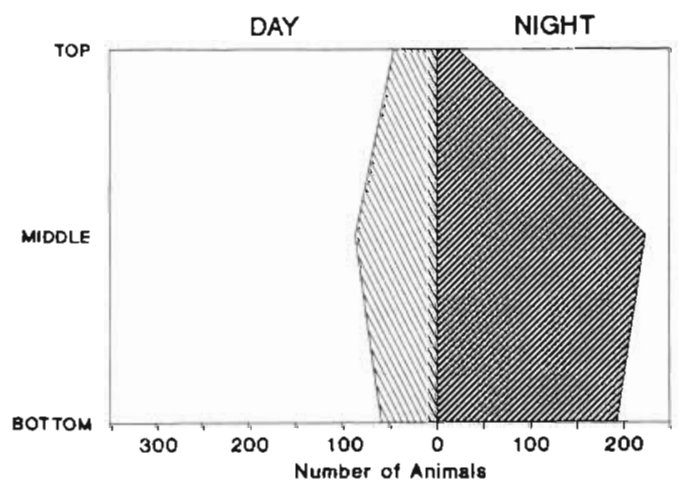

Fig. 4. Eurytemora affinis. Position of copepods in the water-column over diurnal and nocturnal tidal cycles, May 1989. Numbers (per $1 \mathrm{ml}$ subsample) are standardised for $15 \mathrm{~min}$ sampling at each depth (Top, Middle and Bottom of water-column at edge and mid channel). LW: low water normal river flow; FT: flood tide; ET: ebb tide. Distribution of copepods between the 6 sampling positions not related to the amount of water filtered for each tidal cycle $(p<0.005)$. Difference in vertical distribution between tides: LW vs ET and FT vs ET significant at $p<0.005$ for each tidal cycle 
selective tidal transport of far greater sophistication than any so far demonstrated in an estuarine species.

The first manifestation of the strategy is that the maximum net abundance of copepods occurred on different tides with differences in position along the
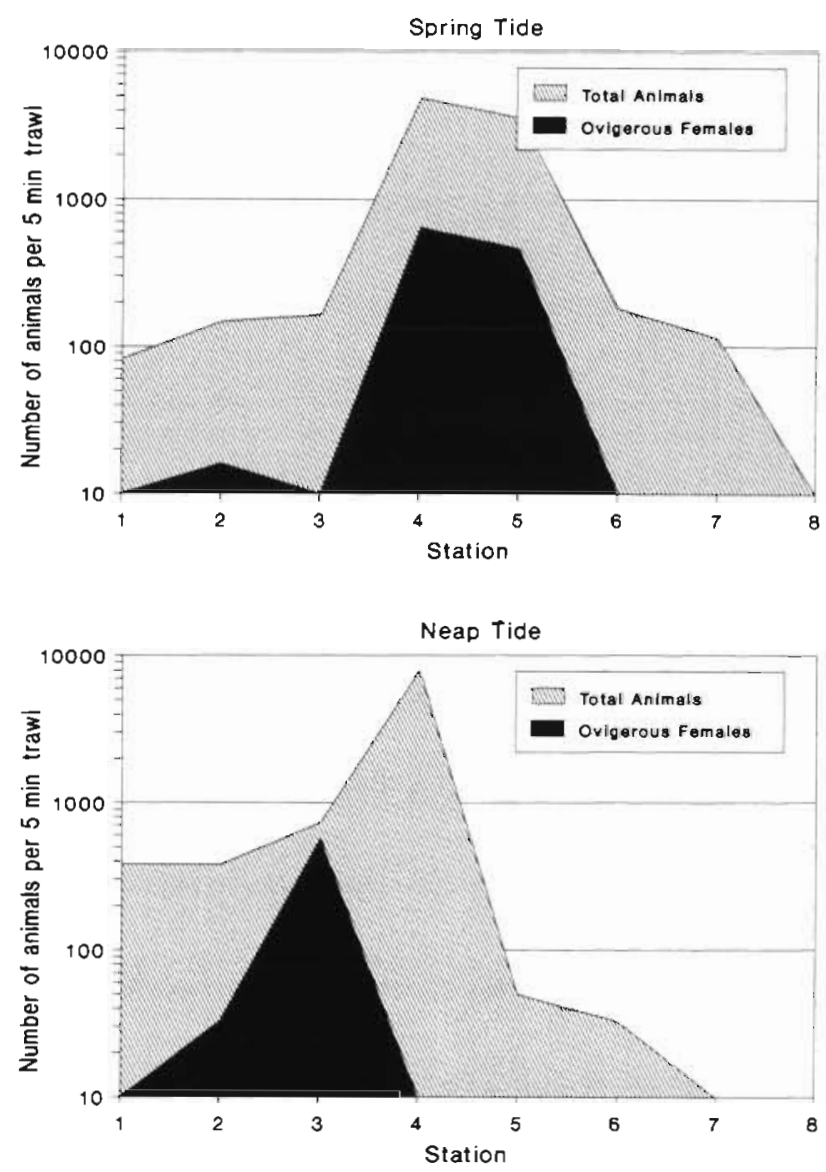

Fig. 5. Eurytemora affinis. Spring and neap distributions of total copepods and ovigerous females along the length of the estuary, November 1989. Stn 1 is at the mouth of the estuary,

Stn 8 approaching the limit of tidal influence estuary. Abundance was maximal on the flood tide near the seaward end of the estuary (Site I) and on the ebb tide at the landward end (Site III), each time on spring tides of increasing amplitude. Data available on physical conditions in the Conwy (Hunter \& Lailey 1980, D. Bowers pers. comm.) indicate that, although velocities increase up-estuary, the constant ratio of flood to ebb tide duration and relative tidal velocities over the period of raised water level would not explain this phenomenon. The only remaining explanation is of a difference in the timing of swimming activity, ensuring presence in the water column on either flood or ebb tides, depending upon the position of copepods along the estuary. The result of such differences in behavioural activity would be to concentrate individuals between Sites I and III, in a specific zone of the estuary. Extensive sampling using 8 stations along the length of the estuary showed the precision of this position maintenance. On each of the 6 sampling occasions there was a discrete region, around 1 or 2 stations, in which the bulk of the population was found.

Comparing the position of the population maximum on spring and neap tides shows considerable semilunar variation; on spring tides the population was always higher up the estuary than on the adjacent neap tides. This difference in positioning corresponds with the differences in tidal swimming activity found when sampling at a constant station (Site I) over the semilunar cycle. On spring tides of increasing amplitude maximum numbers were found on the flood tide, while over spring tides of decreasing amplitude and neap tides, maximum numbers were found on ebbing tides. There is considerable tidal influence at Site I, with a neap tidal range greater than $3 \mathrm{~m}$ (Hunter \& Lailey 1980), and the flood to ebb water velocity ratio is constant over the springs/neaps cycle (D. Bowers pers. comm.). Therefore the biological differences observed over the semi-lunar cycle at that site again cannot be

Table 1. Eurytemora affinis. Centres of population (CoP, see text for procedure) for springs and neaps calculated from the data in Fig. 5, with repeat sampling in March and June, 1990, for total copepods and for ovigerous females separately, together with accompanying physico-chemical parameters: total number of copepods (N), salinity (S) and temperature (T)

\begin{tabular}{|c|c|c|c|c|c|c|c|c|}
\hline & \multicolumn{4}{|c|}{ Total } & \multicolumn{4}{|c|}{ Ovigerous females } \\
\hline & $\mathrm{COP}$ & $N$ & $S \%$ & $\mathrm{~T}\left({ }^{\circ} \mathrm{C}\right)$ & $\mathrm{COP}$ & $N$ & $S \%$ & T $\left({ }^{\circ} \mathrm{C}\right)$ \\
\hline \multicolumn{9}{|l|}{ November } \\
\hline Springs & 4.4 & 10291 & 4.1 & 11.2 & 4.4 & 1128 & 4.1 & 11.2 \\
\hline Neaps & 3.7 & 10176 & 48 & 9.0 & 2.9 & 598 & 11.1 & 9.1 \\
\hline \multicolumn{9}{|l|}{ March } \\
\hline Springs & 5.6 & 4367 & 10.8 & 5.5 & 6.3 & 1258 & 4.2 & 5.5 \\
\hline Neaps & 4.7 & 15769 & 3.1 & 8.0 & 5.0 & 5363 & 0.5 & 7.8 \\
\hline \multicolumn{9}{|l|}{ June } \\
\hline Springs & 5.3 & 6107 & 11.8 & 14.0 & 6.0 & 758 & 2.0 & 14.0 \\
\hline Neaps & 4.8 & 658 & 9.2 & 13.0 & 5.4 & 39 & 1.4 & 13.0 \\
\hline
\end{tabular}


due solely to differences in water flow characteristics. This implies a semi-lunar modulation of tidal swimming activity resulting in the observed differences in distribution along the estuary.

The means by which the copepods effect horizontal movements in the estuary seems to be by a process of tidally-timed vertical migrations. They were found consistently higher in the water column when flow was upestuary on spring tides of increasing amplitude, and appeared to sink when the tide turned. The differences in vertical distributions between day and night tides are presumed to be due to differences in the time of sampling relative to the time of high tide. As water velocity increases logarithmically with distance from the river-bed, upward movements will increase the distance transported, while sinking to the bottom would remove copepods from the water column and so explain the tidally-related differences in numbers caught in the drift-nets. There was no evidence from the present study of any differences in abundance between the edge and middle of the channel. The suggestion that Eurytemora affinis may migrate laterally to avoid tidal currents (Cronin et al. 1962, De Pauw 1973, Roddie et al. 1984) is not therefore supported by present data. Swimming speeds of 2.5 to $5 \mathrm{~mm} \mathrm{~s}^{-1}$ have been recorded in E. affinis (Katona 1973), which would be sufficient to carry copepods into, and out of, fastermoving upper water layers on a tidal basis.

None of the observations on Eurytemora affinis distributions, tidally, vertically or horizontally, can be explained on the basis of the hydrodynamic features of the estuary. It appears therefore that E. affinis possess a finely tuned behavioural mechanism enabling it to maintain its position within a specific region of an estuary. This raises the question of what cues the copepods use in determining their position relative to this 'preferred' zone. The most obvious and reliable factor is salinity (Cronin et al. 1962, Jeffries 1962, De Pauw 1973, Heinle \& Flemer 1975, Von Vaupel-Klein \& Weber 1975, Knatz 1978, Collins \& Williams 1981, Soltanpour-Gargari \& Wellershaus 1985). Von VaupelKlein \& Weber (1975) found peak survivorship between low salinities and $20 \%$, and Roddie et al. (1984) between 3 and $10 \%$. These correspond well with the results reported in the present study, with maximum numbers being found between 0.5 and $11.2 \%$. Zonation relative to salinity would also acount for the differences in semi-lunar position; as the tidal amplitudes increase toward springs the salinity will also increase in the estuary. The differences in positioning of the population maxima with respect to salinity shown in Table 1 could be due to an ability of the copepods to detect only gross salinity levels, leading to a possible time-lag in their ability to change position in synchrony with that of their preferred salinity. Although biotic factors could have an effect in depleting the population of E. affinis at the seaward end of its distribution (Thayer et al. 1974, Bradley 1975, Heinle \& Flemer 1975, Van Vaupel-Klein \& Weber 1975, Knatz 1978, Burkhill \& Kendall 1982), individuals would have to drift downstream into the range of competing or predatory species. This, however, does not appear to occur, and avoidance of competitors or predators by behavioural responses seems unlikely. Also an upstream movement of the species range in summer, as observed by Cronin et al. (1962), Bradley (1975), Heinle \& Flemer (1975), Heckman (1986) and Castel \& Viega (1990) was not apparent in this study, the population maximum in June being no further upstream than that in March. Instead the results suggest a zonation directly related to the tidal range and river discharge, and so to salinity, rather than to one additionally affected by temperature.

That a species such as Eurytemora affinis can maintain such precise distributions in an estuary such as the Conwy, where permanent planktonic populations may not be expected (Ketchum 1954), underlines the potential efficiency of tidally timed vertical migrations in maintaining horizontal position and implies the presence of circa-tidal endogenous swimming rhythms, demonstrated recently by Hough (1990). It also seems probable, given the hydrodynamics of the estuary studied, that similar zonation patterns could be found in other estuarine environments and in other species. This may be particularly relevant to salt-wedge estuaries where sinking would lead to upstream transport. This may explain the absence of eastern North American populations of Eurytemora (e.g. Jeffries 1962, Heinle \& Flemer 1975) from the high salinities in which it occurs in western Europe (De Pauw 1973, Collins \& Williams 1982, this study). Previously published reports of 'estuarine retention' may therefore require more detailed evaluation.

Acknowledgements. We thank. D. Bowers for his explanation of the hydrodynamics of the Conwy Estuary. A.R.H. was supported by a Natural Environment Research Council studentship.

\section{LITERATURE CITED}

Barlow, J. P. (1955). Physical and biological processes determining the distribution of zooplankton in a tidal estuary. Biol. Bull. mar biol. Lab., Woods Hole 109: 211-225

Bosch, H. F. Taylor, W. R. (1973). Diurnal vertical migration of an estuarine cladoceran Podon polyphemoides in the Chesapeake Bay. Mar. Biol. 19: 172-181

Bousfield, E. L. (1955). Ecological control of the occurrence of barnacles in the Miramichi Estuary. Bull. natn. Mus. Can. 137, Biol. Ser. No. 46

Bowden, K. F. (1983). Physical oceanography of coastal waters. Ellis Harwood series in marine science. Wiley, London

Bradley, B. P. (1975). The anomalous influence of salinity and 
temperature on summer and winter populations of the copepod Eurytemora affinis. Biol. Bull. mar. biol. Lab., Woods Hole 148: 26-34

Burkill, P. H., Kendal, T F. (1982). Production of the copepod Eurytemora affinis in the Bristol Channel. Mar. Ecol. Prog. Ser. 7: 21-34

Castel, J., Viega, J (1990). Distribution and retention of the copepod Eurytemora affinis hirundoides in a turbid estuary. Mar. Biol. 107: 119-128

Collins, N. R., Williams, R. (1981). Zooplankton of the Bristol Channel and Severn Estuary. The distribution of four copepods in relation to salinity. Mar. Biol. 64: 273-283

Cronin, T W. (1982). Estuarine retention of larvae of the crab Rhithropanopeus harrisii. Estuar coast. Shelf Sci. 15: $207-220$

Cronin, I W., Daiber, J. C., Hulbert, E. M. (1962). Quantitative aspects of zooplankton in the Delaware River Estuary. Chesapeake Sci. 3: 63-93

De Pauw, N. (1973). On the distribution of Eurytemora affinis (Poppe) (Copepoda) in the Western Scheldt Estuary. Verh. int. Verein. theor. angew. Limnol. 18: 1462-1472

De Wolf, P. (1973). Ecological observations on the mechanisms of dispersal of barnacle larvae during planktonic life and settling. Neth. J. Sea Res. 6: 1-129

De Wolf, P. (1986). Is retention the result of active or passive phenomena? Estuaries 4: 239 (Abstract)

Heckman, C. W. (1986). The anadromous migration of a calanoid copepod, Eurytemora affinis (Poppe, 1880) in the Elbe Estuary. Crustaceana 50: 176-181

Heinle, D. R., Flemer, D. A. (1975). Carbon requirements of the estuarine copepod Eurytemora affinis. Mar. Biol. 31 : $235-247$

Hough, A. R. (1990). Rhythmic behaviour of estuarine Crustacea. Ph. D. thesis, University of Wales, Bangor

Hunter, J. R., Lailey, R. S. (1980). The investigation of the probable effects of the proposed road developments at Conwy: physical study. Report, Unit for Coastal and Estuarine Studies. University of Wales, Bangor

Jeffries, H. P. (1962). Salinity-space distribution of the estuarine copepod genus Eurytemora. Int. Rev. ges. Hydrobiol. Hydrogr. 47: 291-300

Katona, S. K. (1973). Evidence for sex pheromones in planktonic copepods. Limnol. Oceanogr 18: 574-583

Ketchum, B. H. (1954). Relation between circulation and planktonic populations in estuaries. Ecology 35: 191-200

This article was submitted to the editor
Knatz, G. (1978). Succession of copepod species in a Middle Atlantic Estuary. Estuaries 1: 68-71

Knight, D. W., West, J. R. (1975). Preliminary report on conditions in the Conwy Estuary. Internal report, University of Birmingham

McCleave, J. D., Bedaux, J. J. M., Doucet, P. G., Jaeger, J. C., Jong, J. T L., Van der Steen, W. L., Voorzanger, B. (1987). Statistical methods for analysis of plankton and nekton distribution, with application for selective tidal stream transport of juvenile American eels (Anguilla rostrata). J. Cons. int. Explor Mer. 44: 90-103

Pelegri, J. L. (1988). Tidal fronts in estuaries. Estuar. coast. Shelf Sci. 27: 45-60

Roddie, B. D., Leakey, R. J. G., Berry, A. J. (1984). Salinitytemperature tolerance and osmoregulation in Eurytemora affinis (Poppe) (Crustacea: Calanoida) in relation to its distribution in the zooplankton of the upper reaches of the Forth Estuary. J. exp. mar. Biol. Ecol. 79: 191-211

Rogers, H. M. (1940). Occurrence and retention of plankton within the estuary. J. Fish. Res. Bd Can. 5: 164-171

Seliger, H. H., Bloggs, J. A., Rivkin, R. B., Aspden, K. H. R. (1982). The transport of oyster larvae in an estuary. Mar. Biol. 71. 57-72

Soltanpour-Gargari, A., Wellershaus, S. (1985). Eurytemora affinis - one year study of abundance and environmental factors. Veroff. Inst. Meeresforsch. Bremerh. 20: 183-198

Soltanpour-Gargari, A., Wellershaus, S. (1987). Very low salinity stretches in estuaries - the main habitat of Eurytemora affinis, a planktonic copepod. Rep. mar Res. 31 $199-208$

Thayer, G. W., Hoss, D. E., Kjelson, M. A., Hettler, W. F. Jr., LeCroix, M. W (1974). Biomass of zooplankton in the Newport River Estuary and the influence of postlarval fishes. Chesapeake Sci. 15: 9-16

Von Vaupel-Klein, J. C., Weber, R. W. (1975). Distribution of Eurytemora affinis (Copepoda: Calanoidea) in relation to salinity: field and laboratory observations. Neth. J. Sea Res. 9: $297-310$

Wood, L., Hargis, J. H. (1971). Transport of bivalve larvae in a tidal estuary. In: Crisp, D. J. (ed.) Proceedings of the Fourth European Marine Biology Symposium. Cambridge University Press, Cambridge, p. 29-44

Wooldridge, T., Erasmus, T (1980). Utilisation of tidal currents by estuarine zooplankton. Estuar. coast. mar. Sci. 11: $107-114$

Manuscript first received: February 18, 1991

Revised version accepted: July 12, 1991 